\title{
Canada's Potential Growth: Another Victim of the Crisis?
}

Marcello Estevão and Evridiki Tsounta 


\title{
IMF Working Paper
}

Western Hemisphere Department

Canada's Potential Growth: Another Victim of the Crisis?

Prepared by Marcello Estevão and Evridiki Tsounta ${ }^{1}$

Authorized for distribution by Charles Kramer

January 2010

\begin{abstract}

\section{This Working Paper should not be reported as representing the views of the IMF.} The views expressed in this Working Paper are those of the author(s) and do not necessarily represent those of the IMF or IMF policy. Working Papers describe research in progress by the author(s) and are published to elicit comments and to further debate.
\end{abstract}

This study investigates the impact of the current financial crisis on Canada's potential GDP growth. Using a simple accounting framework to decompose trend GDP growth into changes in capital, labor services and total factor productivity, we find a sizeable drop in Canadian potential growth in the short term. The estimated decline of about 1 percentage point originates from a sharply decelerating capital stock accumulation (as investment has dropped steeply) and a rising long-term unemployment rate (which would raise equilibrium unemployment rates). However, over the medium term, we expect Canada's potential GDP growth to gradually rise to around 2 percent, below the pre-crisis growth rate, mostly reflecting the effects of population aging and a secular decline in average working hours.

JEL Classification Numbers: G01, D24, J24, O51, O16, O4

Keywords: Canada, potential growth, TFP, financial crisis, labor productivity Authors’ E-Mail Addresses: mestevao@imf.org, etsounta@imf.org

\footnotetext{
${ }^{1}$ The authors are grateful to Charles Kramer, Nicoletta Batini, Lev Ratnovski, Isabelle Amano, Bing-Sun Wong and seminar participants at Finance Canada for their useful comments and insights. We are particularly indebted to Natalia Barrera for all her research support in undertaking this project. Thomas Dowling and Geoff Keim provided excellent research assistance, while Joanna Meza-Cuadra and Hildi Wicker-Deady provided production assistance. All remaining errors are ours.
} 


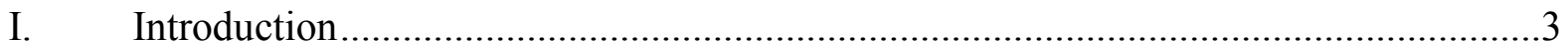

II. Some Theoretical Considerations …......................................................................

III. Impact of Past Financial Crises on Potential ......................................................5

IV. Productivity Developments in the Canadian Business Sector .................................

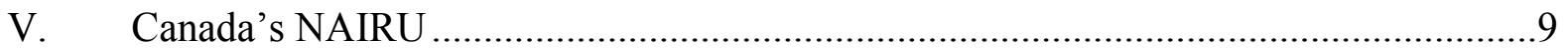

VI. A Simple Framework to Decompose and Project Potential GDP Growth .................10

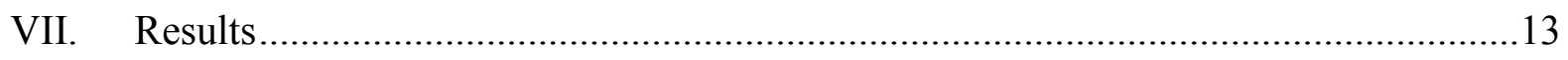

VIII. A Look at Past Canadian Recessions ............................................................. 17

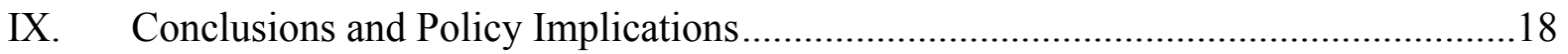

Tables

1. Path for Potential Output Growth Components ........................................................26

2. Path for Potential Output Growth Components During Recent Canadian Downturn .........27

Figure

1. Canada: Potential Output Growth .............................................................................25

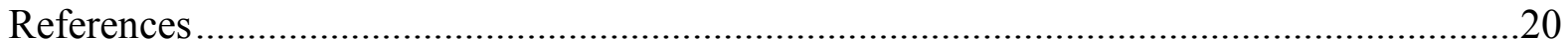

Annex

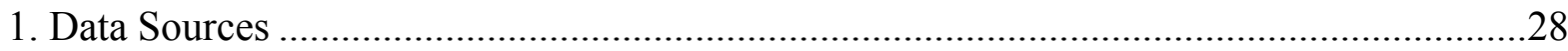




\section{INTRODUCTION}

Policy makers need accurate estimates of the amount of economic slack, but this usually difficult exercise has become even harder during the ongoing financial crisis. The most common measure of slack is the output gap, i.e. the difference between actual production and a notional amount that could be produced using all available resources without strains on their price - the potential output of a country. With this measure at hand, monetary and fiscal authorities can evaluate inflationary and structural fiscal pressures. In particular, the timing of exit strategies from the unusual level of policy stimulus in developed economies depends closely on the size of this gap. However, potential output is not directly observable and economists need to take a stance on how its determinants will evolve, including future capital accumulation, equilibrium unemployment rates, and total factor productivity (TFP). In the current juncture, the uncertainty surrounding these estimates is especially large as the impact of severe financial shocks on these variables is unknown, and other factors (i.e., sectoral reallocation) are also at play.

This paper assesses the impact of the recent financial crisis on Canada's potential growth. For example, tighter financial conditions could deter efficient capital allocation and possibly slow Canadian potential growth. The protracted recession and tighter financial conditions have already hurt investment (down almost 15 percent since end-2008Q2) and thus capital accumulation, while higher unemployment rate will affect equilibrium rates of unemployment-both lowering potential growth. While the impact of the financial crisis on total factor productivity (TFP) is not known a priori, some recent evidence point for a negative correlation between financial shocks and TFP growth (Estevão and Severo, 2009) and even if a countervailing factor were in place, past TFP dynamics have not compensated for variations in capital and labor services in Canada. Thus, bearing in mind the downward pressures on potential growth from trends in working age population (mostly from aging) and hours worked per employee (a secular trend), we project that potential GDP growth in Canada would decline significantly in the coming years amid the crisis (by almost 1 percentage point), gradually rising to around 2 percent by 2014 (below the estimated 2.4 percent potential growth for 2008). Potential GDP level would suffer a permanent decline of about $2 \frac{1}{2}$ percent vis-à-vis a no-crisis scenario; a modest loss compared to previous financial crises in industrialized countries (Cerra and Saxena, 2008, and WEO, 2009).

The paper is structured as follows. Section II describes what theory predicts would be the impact of the crisis on potential GDP growth, while Section III reviews recent empirical findings on this impact. The remaining two sections look at Canada's labor productivity and non-accelerating inflation rate of unemployment (NAIRU) performance over the years, while Section VI describes a simple framework to decompose and project potential GDP growth. The results, compared and contrasted with other studies, are presented in Section VII, while section VIII compares our findings with Canada's previous downturns. Section IX concludes and offers some policy implications. 


\section{Some Theoretical Considerations}

In the short term, a sizeable drop on Canadian potential growth could originate from the sharply decelerating capital stock accumulation (as investment and capacity utilization have dropped steeply) and rising long-term unemployment would raise equilibrium unemployment rates. $^{2}$

However, in general theory does not predict a particular effect of the financial crisis on potential output:

- $\quad$ The impact of the crisis on labor input is unclear. On the one hand, a long and deep recession could cut the potential labor force by discouraging labor participation and migration flows (European Commission, 2009; Elmeskov and Pichelman, 1993). On the other hand, the huge depletion of savings following the stock market and housing decline could potentially encourage workers to extend their working life past their originally planned retirement age or induce idled secondary earners to enter the labor market. ${ }^{3}$ Debelle and Vickery (1998) show that the latter effect is particularly relevant to explain the labor force participation of female secondaryearners. We also expect a temporary increase in the non-accelerating inflation rate of unemployment (NAIRU, also referred to as structural unemployment in this paper) from the crisis given possible hystereses effects (Ball, 2009; Blanchard and Summers, 1989). The effect on NAIRU and any changes in the participation rate are expected to be only temporary and not affect medium-term trends, given that labor markets are quite flexible in Canada (just like in the United States). ${ }^{4}$ Beyond the crisis, demographic forces will contribute negatively to potential growth. ${ }^{5}$

- $\quad$ The impact of the crisis on capital accumulation could be significant. Financial crises lower incentives to invest in capital by decreasing sales and raising uncertainty on investment returns and risk premia. In addition, credit supply is, in general, lower during a financial crisis, reflecting tighter lending standards (both in

\footnotetext{
${ }^{2}$ In this analysis, we ignore the indirect effects to potential output from stabilization policies in response to the crisis. For such a discussion, please refer to Furceri and Mourougane (2009).

${ }^{3}$ Household's net worth is down C\$52.3 billion in Canada from its peak in the third quarter of 2008 and over $\$ 12.2$ trillion from its peak in the third quarter of 2007 in the United States.

${ }^{4}$ Balakrishnan (2008) finds that Canada's labor market is as efficient as the one in the United States. Labor market flexibility is reflected in the significant and immediate impact of the Canadian downturn on the unemployment rate, which increased from 6.2 percent in September 2008 to 8.6 percent in October.

${ }^{5}$ Stats Canada's baseline projections indicate that between 2006 and 2011, working-age population will rise by a cumulative 4.4 percent versus over 13 percent increase in the elderly population. This discrepancy increases over time; by 2031, the elderly population more than doubles (compared to 2006) while the size of the workingage population only increases by 8 percent.
} 
terms of price and non-price factors for corporations) as financial institutions work to fix their balance sheet. Canada has indeed experienced a large drop in investment since mid-2008, which will provoke much slower growth in the capital stock and, thus, on potential growth. The longer-term effects on investment will depend on the resilience of high capital costs and on investors' attitudes towards risk.

- $\quad$ The impact on TFP is uncertain a priori. On the TFP front, Canada has lagged the United States, and the current crisis is not projected to ameliorate this gap. TFP could be negatively affected by the crisis if economic uncertainty and higher capital costs deter private investment in R\&D and innovation which, as indicated by the OECD (2006) is already low in Canada by international comparisons. On the other hand, firms might decide to undertake reforms and restructuring to improve efficiency given the crises, boosting TFP. The final effect on TFP growth could depend on industries' characteristics. For instance, Estevão and Severo (2009) show that financial shocks affect TFP growth through their effect on factor allocation, which in turn depends on an industry's degree of reliance on external funding and whether the financial shock affects firms differently within each industry. The model presented shows that TFP growth in an industry would decline if banks' tightened lending standards cause higher heterogeneity in capital costs within an industry. That would force the market equilibrium further away from an optimal allocation of resources as done by, say, a social planner, thus reducing industry's TFP growth. They show that for the period going from 1990 to 2007 and using data for 31 industries in the United States and Canada, financial shocks indeed tended to lower TFP growth.

\section{ImPact of Past Financial Crises on Potential}

Past research suggests that financial crises could permanently affect potential growth. Furceri and Mourougane (2009), using a univariate autoregressive growth equation for a group of 30 OECD countries for the period 1960-2007, find that financial crises negatively and permanently affect potential GDP. Furceri and Mourougane show that, on average, past financial crises have lowered potential GDP level permanently by 1.5-2.4 percent, with some countries having potential output declining by as much as 4 percent. They also find that the magnitude of the effect increases with the severity of the crisis. This is in contrast with Haugh et al. (2009) who find mixed effects from crises on potential output, based on an events-study approach. Looking at a sample of EU and OECD countries over the period 1970-2007, a recent European Commission analysis (European Commission, 2009) finds that each year of a banking crisis (which lasts, on average, 3.9 years) is associated with a drop in potential GDP per capita growth of around 0.5 percentage point, with partial restoration of growth rates during the recovery years; though there is a permanent loss in 
potential GDP level that is not recovered (also found in IMF (2009a, b). ${ }^{6}$ Cerra and Saxena (2008) estimate a permanent output loss of 4 to 16 percent following financial crises in developed and less developed countries.

Financial crises result in large output losses with protracted recovery. Reinhart and Rogoff (2009) reviewed several recent financial crises and found that they are accompanied by recessions with large losses in output and employment that last longer than "typical" episodes by an average of one year. Haugh et al. (2009) also find that during financial crises output losses are typically (two to three times) greater than during "normal recessions," again with a more protracted recovery. Cerra and Saxena (2008) find that for 14 OECD countries, economic contractions are not typically followed by fast recoveries, with crises leading to lower long-term growth.

Past financial crisis had severe Contribution of Finance, Insurance, and Real and long lasting effects on Canadian output. For example, during the 1980 s recession (which was accompanied by a severe housing downturn) the contribution of Finance, Insurance, and Real Estate (FIRE) to Canadian GDP growth was negative, while in the milder 1991 recession, the growth rate of FIRE output decelerated from 3.8 percent in 1990-91 to 2.5 percent in 1992. On the onset of the current crisis, FIRE's growth rate Estate to GDP Growth, 1980-2009 (in percentage points)

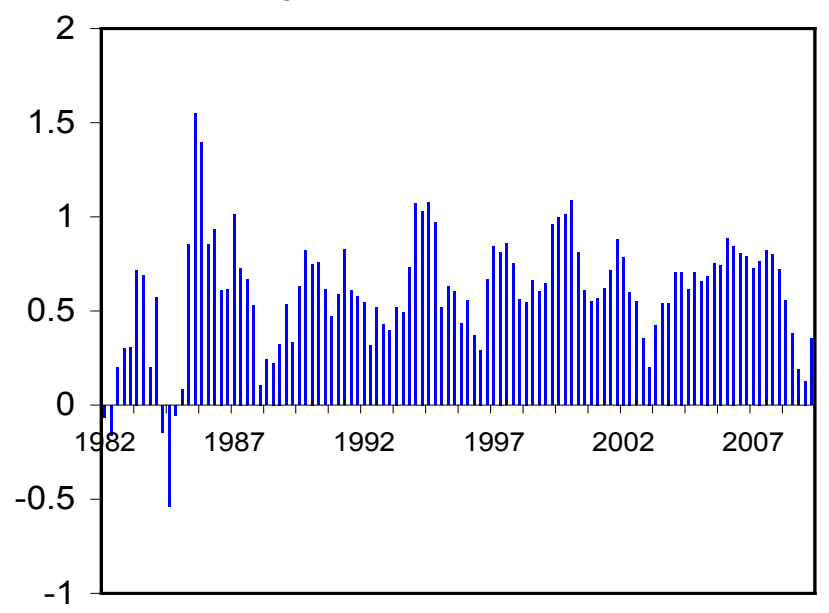

Sources: Haver Analytics; and Authors' estimates. decelerated significantly but did not turn negative averaging around 1 percent for the last year, with signs pointing to some improvement going forward, possibly relating to the underlying strength of the FIRE sector in Canada.

\footnotetext{
${ }^{6}$ For a more extensive discussion on recent literature analyzing the effects of financial crises on GDP and potential GDP growth, please refer to European Commission (2009) and IMF (2009a, b).
} 


\section{Productivity Developments in the Canadian Business Sector ${ }^{7}$}

Labor productivity growth has decelerated significantly in Canada in the last decade. Baldwin and $\mathrm{Gu}$ (2009) analyze labor productivity growth in Canada and in the United States between 1961 and 2008. Over the past 50 years, productivity in Canada has increased by around 2 percent per year, compared with 2.3 percent in the United States. However, in recent years, the gap in productivity growth between the two countries has widened steadily. From 2000 to 2008, labor productivity in Canada's business sector increased at an annual average rate of 0.7 percent versus 2.6 percent in the United States. This is in sharp contrast with the Canadian performance prior to the mid-1980s, when productivity growth in Canada was faster than in the United States. Between 1961 and 1980, labor productivity in Canada increased 2.9 percent a year on average, faster than the rate of 2.5 percent in the United States. More recently, between 1997-2000, Canadian labor productivity grew by 3.2 percent before decelerating significantly to a mere 1.1 percent and declining by 1 percent in 2008 .

Using a production function approach, past research finds that total factor productivity (TFP) explains most of the recent slowdown in Canadian labor productivity growth. Baldwin and $\mathrm{Gu}$ (2009) find that the recent slowdown is explained by slower TFP growth while earlier declines were mostly driven by lower contribution from capital deepening. They find that Canadian TFP has actually declined in recent years; from growing by an annual average of 0.3 percent between 1980-2000 to declining by 0.6 percent in the period 2000-08 (with Canada-U.S. labor productivity growth gap at 1.9 percentage points per year in the 2000-08 period). ${ }^{8}$ Statistics Canada (2007a) finds that TFP was an important driving force behind U.S. labor productivity growth in recent years: at 1.5 percent a year for 1996-2006 it was more than double the Canadian figure ( 0.6 percent a year). Rao et al. (2008) also find that most of the widening gap between Canadian and U.S. labor productivity is explained by TFP performance.

Turning to a sectoral view of productivity developments, past research has found mixed evidence on the source for the performance gap between the two countries. Cardarelli and Kose (2004) find that the widening labor productivity gap in the United States and Canada over the 1990s is a reflection of different evolution of industrial structures: the United States has benefited from dramatic labor productivity acceleration in the service sector, magnified for the larger share of services in U.S. production. Cardarelli (2004) finds that two key service sectors account for most of the gap, namely trade, and finance, insurance and real

\footnotetext{
${ }^{7}$ While this section is concentrated to output of the business sector, our overall analysis focuses on the output of the total economy, i.e., it also includes the non-business sector.

${ }^{8}$ Baldwin and $\mathrm{Gu}(2009)$ estimate that the average annual growth rate of TFP in the United States over the period 1961-2008 was 0.9 percentage points higher than in Canada.
} 
estate (FIRE). On the other hand, Baldwin and Gu (2009) claim that the recent Canadian labor productivity slowdown is primarily explained by slower performance in mining, oil and gas extraction as well as in manufacturing, possibly related to an appreciating Canadian dollar. ${ }^{9}$ The former accounts for 0.6 percentage point of the post-2000 deceleration in labor productivity while manufacturing accounts for 0.5 percentage point. They claim that the slowdown in FIRE is only responsible for 0.2 percentage point of the deceleration in labor productivity growth. Rao et al. (2005) assert that it is hard to isolate the factors explaining the slower Canadian productivity growth in recent years given numerous factors at place at the same time including a productivity collapse in ICT-producing industries, cyclical factors, rapid increase in commodity prices, and the appreciation of the Canadian dollar.

The decline in labor productivity in 2008 originates mostly from the goods-producing sector, which has contracted by almost 3 percent (driven by the construction and manufacturing sectors). The decline in manufacturing labor productivity has also continued in 2009 , while there has been a sharp reversal in the construction sector (rising by over 5 percent through the year ending in the second quarter of 2009). The services sector now also suffers from declining labor productivity-though its decline is small (averages -0.2 percent in the last three quarters), with large declines in wholesale trade and FIRE. Overall, Canada's business labor productivity has been unchanged (year-on-year) at the end of the second quarter of 2009.

Going forward, under this sectoral approach, lower financial sector activity would affect potential growth via two channels. The direct effect would be through lower growth in the output of FIRE (which contributed about a fourth of aggregate output growth in the last decade) and indirectly through reduced activity elsewhere in the economy, as credit tightening raises capital costs. These effects would be amplified by the sectoral restructuring already underway in Canada, as production of manufacturing shrinks and resources are transferred to the less productive energy sector. Indeed, the share of manufacturing in Canada's real GDP at basic prices has fallen from around 18 percent in the early 2000s to around 13 percent nowadays. Mining and oil extraction's share has been relatively unchanged at around 4 to 5 percent of GDP.

\footnotetext{
9 The importance of the mining sector in explaining the slowdown in Canadian TFP is also consistent with Statistics Canada's findings (cited in Sharpe and Arsenault, 2009) that Alberta's annual labor productivity growth is the smallest in Canada during 1997-2007 (at 1 percent), closely followed by British Columbia at 1.2 percent. Ontario and Quebec were at the middle of the sample, with average annual labor productivity growth rate of around 1.7 percent, while Newfoundland was leading with almost 5 percent annual growth rate. In terms of TFP performance, Alberta's average TFP declined by an annual average of 1.6 percent, while again Newfoundland was leading with annual TFP growth of over 4 percent during the same period. Quebec and Ontario's TFP growth was around 0.9 percent per annum while British Columbia's TFP has been growing by around 0.5 percent per year, one-tenth of a percentage point above the national average.
} 


\section{CANADA's NAIRU}

Analysts have a range of estimates for the NAIRU in Canada, but there is a consensus that it had been declining up to the beginning of the current crisis. ${ }^{10}$ Richardson et al. (2000) find that the NAIRU has been declining steadily in Canada. Rose (1988) estimates that the NAIRU for Canada at the end of 1987 was about 8 percent, but notes factors working to reduce it over the medium term. Sharpe and Sargent (2000), after summarizing the work of various authors, indicate a strong consensus that structural unemployment has fallen in the 1990s. Estimates of the Canadian NAIRU range from a high of 9.5 percent to a low of 6.5 percent with the average estimate being 7.7 percent (OECD 1996) in the mid-1990s. ${ }^{11}$ Fortin (2000) finds that during the 1990s, the lowest sustainable rate of unemployment (LSRU) in Canada declined from the 7.5 to 8 percent range to around 6 percent by $2000 .{ }^{12}$ Sharpe (1996) estimates that a reasonable estimate of the NAIRU in 1994 was around 7.5 percent in Canada and around six percent in the United States. To explain the structural differences, the author examines unemployment insurance in both countries. In Canada, the unemployment insurance system is more generous than in the United States, offering a higher benefit replacement rate and more extensive coverage as well as requiring less prior work than the typical program in the United States. Research indicates that the greater generosity of the Canadian system lowers labor force participation and increases the duration of unemployment in Canada relative to the United States (Sharpe, 2001; Fortin and Fortin, 1999). ${ }^{13}$

Several reasons have been cited for the decline in the NAIRU in the 1990s. Those include the drop in the relative size of the youth labor force-a group experiencing above-average unemployment; higher average education level of the labor force; deregulation in the domestic economy, and free trade and globalization in the world economy, which increased labor and product competitiveness; and the decline in unemployment insurance generosity both in terms of lower benefits and stiffer eligibility criteria (Fortin, 2000). Other factors that could potentially explain a lower NAIRU include increased female labor force participation

\footnotetext{
${ }^{10}$ Estimates of the NAIRU in general are very sensitive to methodological choices (Setterfield et al., 1992; Staiger et al., 1997) and therefore should be interpreted with considerable caution. Finance Canada defines that "structural unemployment occurs when workers are unable to fill available jobs because they lack the skills, do not live where jobs are available, or are unwilling to work at the wage rate offered in the market." Jackson (2005) discusses studies estimating the NAIRU from mid-1980s to mid-1990s in Canada.

${ }^{11}$ The large range of estimates indicates the degree of uncertainty in estimating this unobservable series.

${ }^{12}$ Within the old-fashioned vertical long-term Phillips curve framework, the LSRU concept (proposed by Modigliani and Papademos, 1975) is the same as that of the NAIRU. But the LSRU is a broader concept than the NAIRU since it can also apply to the non-vertical, long-term Phillips curves arising from theories such as proposed by Eckstein and Brinner (1972); Tobin (1972); Akerlof, Dickens and Perry (2000).
}

13 Betcherman (2000) looks at evidence of the importance of labor market policies and institutions for structural unemployment and finds that the generosity of the unemployment insurance system has been systemically associated with higher levels of unemployment across OECD countries. 
rate since the mid-1990s; Tsounta (2006) finds that reforms in the tax and benefit system increased labor force participation for secondary earners in a household and thus could be important in explaining the decline in the NAIRU since the mid-1990s.

The NAIRU is estimated to have declined further in the 2000s but the current crisis will probably raise it again, at least temporarily. Sharpe and Sargent (2000) indicate that the decline in the unemployment rate in the 2000s below previous NAIRU estimates coupled with low inflation rates indicate that the structural rate of unemployment has fallen in the 2000s. However, with unemployment rates hovering around an 11-year high, and given the assumed protracted recovery, we expect a temporary increase in structural unemployment (given human capital depletion) which should return to its pre-crisis levels over the medium term, given Canada's flexible labor markets.

\section{A Simple Framework to Decompose and Project Potential GDP Growth}

Aggregate data and trends show that potential growth has been decelerating since 1999 . Following Barrera et al. (2009), we decompose potential GDP growth into changes in (i) capital stock, (ii) equilibrium capital utilization; (iii) trend hours of work per employee;

(iv) the equilibrium rate of unemployment (or NAIRU); trend labor force participation rate;

(vi) working-age population; and (vii) trend TFP. ${ }^{14}$ The decomposition begins by first calculating TFP level according to:

$$
t f p=y-\alpha k s-\alpha k u-(1-\alpha) l
$$

Where $x$ refers to the logarithm of $x, y$ is output, $k s$ is the capital stock, $k u$ is capital utilization (proxied by a measure of capacity utilization in the industry estimated by Statistics Canada), $l$ is total labor hours, and tfp is total factor productivity. Once, TFP level is obtained, potential output is calculated as:

$y^{*=} \alpha k s+\alpha k u^{*}+(1-\alpha) h^{*}+(1-\alpha)\left(1-u^{*}\right)+(1-\alpha) l f p^{*}+(1-\alpha) w a p+t f p^{*}$

Where $h$ is average hours of work, $u$ is the unemployment rate, lfp is the labor force participation rate, and wap is working-age population. Variables with a * are trend values obtained using an HP filter for all series assuming a smoothness parameter, $\lambda$, of 100 - the traditional value for annual-frequency data. ${ }^{15}$ All variables refer to the whole Canadian

\footnotetext{
${ }^{14}$ Details on data used and the methodology are provided in the Annex.

${ }^{15}$ For a discussion of the advantages and disadvantages of using statistical filters to estimate potential output, refer to Cotis et al. (2005). Possible extensions of the study could include using different filtering techniques, for instance a lower smoothness parameter as suggested by Ravn and Uhlig (2002) or filtering a longer series (including projections of the raw series) instead of projecting the trend variables.
} 
economy, and growth rates are constructed using the level data. The average share of labor compensation in value added used in the calculation as a proxy for $(1-\alpha)$ is equal to 0.62 ; according to Sharpe and Arsenault (2009), the labor share in Canada hovers around 0.6 percent with the capital share around 0.4 , and Sharpe et al. (2008) offer more details on Canada's labor share in total value added. ${ }^{16}$ Data on capital are taken from the OECD Economic Outlook database and labor data are based on Statistics Canada's Labor Force Survey.

Past data illustrate, in particular, ongoing demographic shifts and broad TFP trends. (Figure 1, Table 1) The data show clearly that, even before the crisis, growth in working-age population and hours worked per employee had been declining, while the NAIRU was falling and participation rate was rising (given the reforms of the 1990s in employment insurance and tax and benefit system analyzed earlier). On net, trend labor input growth declined in the last years of the sample. The filtered TFP growth does not show large variations but captures the increase in post-1990s, also observed by Statistics Canada (2007) where average annual TFP growth in Canada rose by 0.6 percent per year between 1997-2007.

Looking ahead, potential growth is expected to slow down given the financial crisis. Staff has allocated further reductions in potential growth across slower capital accumulation, temporarily higher NAIRU, continuing declines in hours worked per employee, with essentially unchanged TFP growth in the next couple of years. The exact path for each of these variables should be seen as illustrative and it is consistent with the experience of these variables in past crises as indicated in the next section and broadly in line with the earlier discussion in theoretical issues and past research. Notice that in the absence of a final verdict on TFP growth given the varied factors discussed before, we opted to keep it about unchanged throughout the crisis and subsequent period. Key factors determining future potential growth are:

- The October 2009 WEO forecast has gross private fixed investment declining by 13.5 percent in 2009, similar to the 13.7 decline experienced during the 1982 recession (by mid-2009, investment was 14.8 percent lower than a year ago). ${ }^{17}$ For 2010, we expect gross private fixed investment to remain at its 2009 levels as corporations remain hesitant to invest more aggressively given the economic uncertainties, low levels of capacity utilization, and the still tight lending conditions. Following these sharp declines, investment is set to return slowly to near pre-crisis

\footnotetext{
${ }^{16}$ Robidoux and Wong (2003) indicate that the TFP gap between the United States and Canada might be smaller when using time-varying capital and labor income shares. Throughout the analysis we choose to keep the income shares constant so as to isolate the impact of income share changes to potential GDP growth changes.

${ }^{17}$ The sharp slowdown in capital accumulation reflects distressed banking systems worldwide and the global financial instability which has led to considerable uncertainty and misallocation of resources.
} 
ratios to output at the end of the forecast horizon (at around 17.3 percent of nominal GDP). Using a perpetual inventory method, including by accounting for a historical rate of depreciation of around 8 percent a year, we obtain the path for the growth in the capital stock shown in Figure 1 and Table $1 .{ }^{18}$ The weak investment dynamics is key to future potential growth, as the WEO forecast is predicated on protracted (i) tight financial conditions internationally; important for Canadian firms which rely on U.S. sources for raising around 25 percent of their capital (IMF, 2008) and

(ii) recovery in foreign demand given the U.S. economic outlook. These assumptions are in line with those of the European Commission (2009), which finds that for past EU crises the contribution of capital accumulation to potential growth does not slow down significantly over the long-term, though there is a short to medium-run deceleration in capital accumulation in the aftermath of the crisis.

- By fitting an HP filter to actual Canadian unemployment rates, we estimate a measure of the NAIRU. This procedure has the advantage of being simple and appears to be consistent with other estimates in the literature. We observe the widely documented declining trend in NAIRU over the 1990s and 2000s; however, unlike Fortin (2000) which estimates that the NAIRU has fallen to 6 percent in early 2000 , our estimates suggest that NAIRU could have fallen to around 6 percent

Estimated NAIRU (in percent)

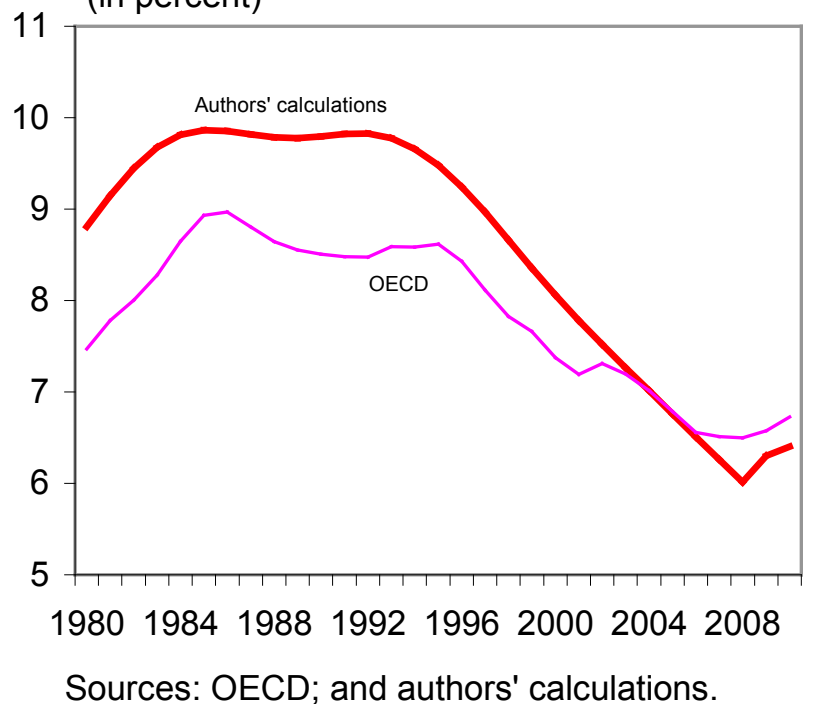
only by 2008 , possibly due to the hystereses effects of unemployment amid improved macroeconomic conditions. ${ }^{19}$ Going forward and consistent with the experience during past downturns, we forecast

\footnotetext{
${ }^{18}$ Statistics Canada (2007b) indicates that Canada's depreciation rate is greater than the rates observed in the United States due to higher depreciation in building and engineering construction. While both countries have similar depreciation rates for machinery and equipment asset classes (18 percent on average in the United States and 20 percent in Canada), there is a considerable difference between Canadian and U.S. depreciation rates for buildings and engineering construction (U.S. rate is 3 percent versus an 8 percent Canadian average).

${ }^{19}$ Fortin (2000) paraphrasing two former chairmen of the U.S. Council of Economic Advisers, notes that high unemployment rates could be even worse than we thought because they raise structural unemployment, while low rates could be even better than we thought because they reduce structural unemployment (Okun 1973; Stiglitz 1997).
} 
a path that mirrors historic relationships between filtered series and the actual unemployment rate. Starting in 2011, there is an increase in the contribution of labor to potential growth, consistent with the European Commission's (2009) finding that after a severe recession in most countries, labor services contribution rises amid declining NAIRU during the recovery.

- Given the sharp increase in labor force participation in the last decade, we are assuming that labor participation would remain essentially unchanged over the medium term (rising by a negligible amount as older individuals might choose to remain longer in the labor force to rebuild lost savings or second earners might choose to enter the labor market).

$\circ$ Growth in working-age population (individuals aged 16-65 years) is set to decline slowly in the next few years, according to projections from Statistics Canada (baseline scenario).

- Average hours of work are assumed to continue its long-term downward trend in the coming years.

- Equilibrium capacity utilization in Canadian non-farm goods-producing industries (a proxy for overall Canadian capital utilization) has been on a declining trend since the early 2000s, after rising during the 1990s. For the remaining forecast period, we assume it would remain essentially constant.

- Trend aggregate TFP growth is relatively smooth, rising by around 0.4 percent per year in the last decade, after falling in the 1990s. Following the experience from past crises in Canada, we don't expect TFP changes to be the driving force behind longrun potential growth; some minor decline in TFP growth is assumed over the medium term given resource reallocations within industries, and between industries and provinces, which may affect productivity in the near term. However, the immediate impact from the crisis on TFP appears tamed so far. ${ }^{20}$

\section{RESUlts}

Our historical estimates of potential growth are broadly consistent with those of the Bank of Canada and the OECD. For example, Bank of Canada (2008) estimates that Canada's 2007 potential growth has been 2.6 percent in line with our estimate of 2.5 percent, while in its 2002 Monetary Policy Report (Bank of Canada, 2002), it has estimated its 2002-03 potential growth at 3 percent (in line with our 2.9 percent). Bank of Canada (2005) also indicates the

\footnotetext{
${ }^{20}$ For a discussion of trend TFP for industrial countries during financial crises, refer to Haugh et al. (2009).
} 
declining trend in potential GDP; potential GDP has declined from around 4 percent in 1999 (ours is at around 3.8 percent) to about 2.5 percent (ours at 2.9) in 2002. For 2008, however, the Bank of Canada estimates that potential growth was only 1.7 percent (from 2.6 percent in 2007) while our estimate is at 2.4 percent (slightly lower than our 2007 estimate). Recent estimates of potential GDP growth by the OECD and Bishop and Burleton (2009) are also in line with ours.

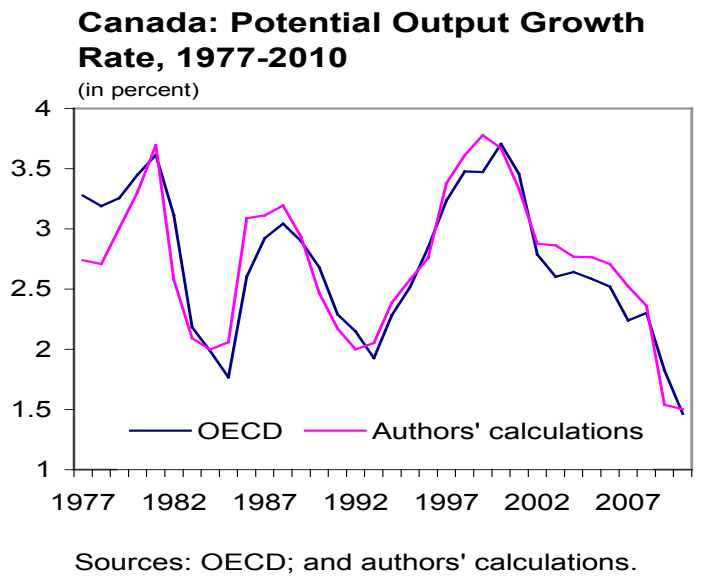

\begin{tabular}{|c|c|c|}
\hline \multicolumn{3}{|c|}{ Comparing Potential GDP Growth } \\
\hline & $2002-03$ & 2007 \\
\hline Bank of Canada & 3.0 & 2.6 \\
\hline Authors & 2.9 & 2.5 \\
\hline
\end{tabular}

Our productivity series is consistent with findings from Statistics Canada for the period 1997-2007. We also find that TFP has increased by an average of 0.4 percent per year. However, unlike Stats Canada we find that TFP hovers around 0.4 percent throughout the period 1997-2007; instead Statistics Canada finds that in the period 1997-2000 TFP was growing more strongly at 2 percent per year, while the period since 2000 saw a decline of TFP of around 0.2 percent per year. Looking at more historical data, similar to Robidoux and Wong (2003) and Armstrong et al. (2002) we find that TFP has stalled in the 1980s (contracting by an annual average of -0.1 percent in the period 1977-1988).

Estimated potential output growth lies between 1.5 and 2 percent for the next five years (Figure 1 and Table 1). After being hit severely by the capital growth dynamics and the projected temporary increase in the NAIRU, potential growth converges slowly towards 2 percent in 2014-below its pre-crisis average-but consistent with estimates of potential growth in the absence of the crisis. Before the crisis, we had projected that potential growth would fall towards 2 percent as a result of population aging, stabilizing female labor force participation following a persistently rising trend since the mid-1990s, and the ongoing restructuring of the Canadian industrial structure. The average potential growth rate for 2009-14 turns out to be $13 / 4$ percent, around 0.3 percentage points below our estimates for potential growth in the absence of the crisis. The resulting paths for the output gap and the unemployment gap (defined as the difference between actual unemployment rates and the NAIRU are shown below, and closely mimic the performance in the 1980 s crisis. The output gap reaches its widest point in 2009 at about similar levels as in the 1982 recession, while the unemployment gap peaks in 2010 (given the usual lags in unemployment dynamics). 


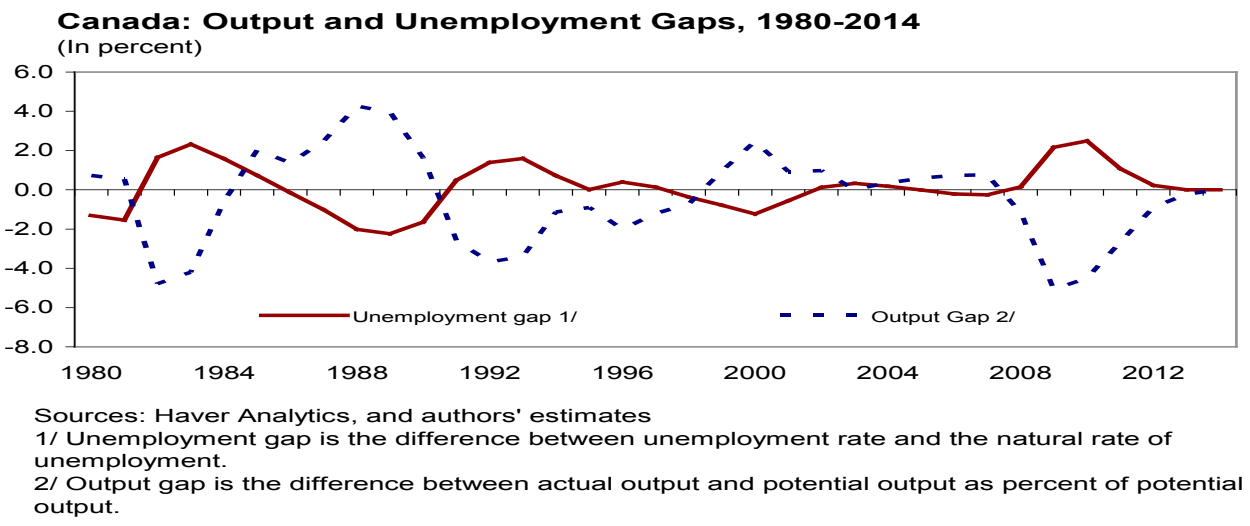

Ultimate losses in potential output are in the ball park of previous research. By 2014, potential output is expected to be about 2.4 percent below the counterfactual level produced by assuming a gradual decline of potential GDP from 2.4 percent in 2008 to 2 percent in 2014 (as assumed by the IMF before the crisis erupted). ${ }^{21}$ This gap is in line with the ones observed after previous financial crises as documented in Furceri and Mourougane (2009), but a bit lower than the interval estimated by Cerra and Saxena (2008) of 4 to 16 percent permanent output loss following financial crises in developed and less developed countries.

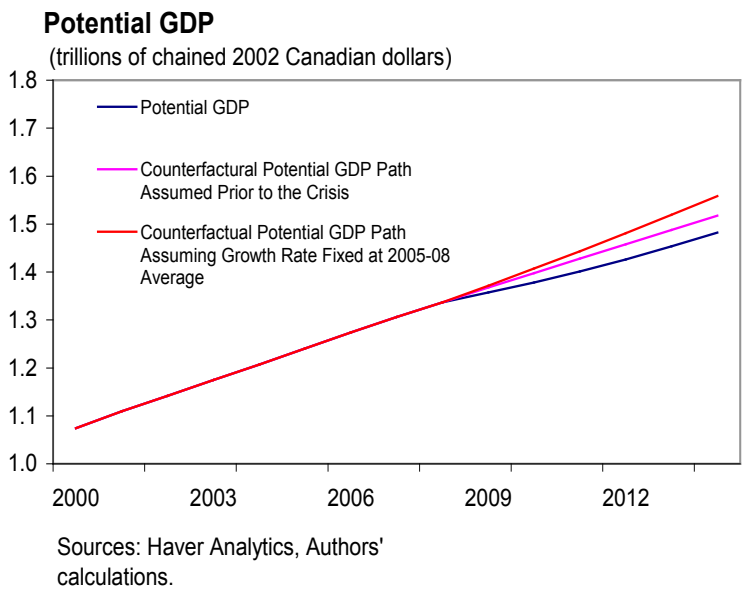

\begin{tabular}{|lcc|}
\hline \multicolumn{2}{|c|}{$\begin{array}{c}\text { Comparison with Statistics Canada Results, 1997-2007 } \\
\text { (contibution to annual average growth rates) }\end{array}$} \\
\hline & \multicolumn{1}{c}{ Authors' estimates } & Statistics Canada \\
\cline { 2 - 2 } & 1.5 & 1.7 \\
Labor productivity & $\ldots$ & 0.3 \\
Labor composition & 1.1 & 1.0 \\
Capital services & 0.4 & 0.4 \\
Total Factor Productivity & \\
\hline Sources: Authors' calculations; and Statistics Canada cited in Sharpe and \\
Arsenault (2009).
\end{tabular}

\footnotetext{
${ }^{21}$ The loss in potential output would have been around 5 percent assuming potential output grows from 2009 to 2014 at the same average rate observed in 2005-08.
} 
Canada's potential growth over time closely mimics the U.S. performance. European Commission (2009) finds that potential growth rates in the United States and the EU-12 countries (a proxy for the euro area) have generally being trending downwards since the late 1980s, with a pause in the United States in the mid-1990s driven by the ICT-related upsurge, which only lasted until 2000 (Barrera et al., 2009). We find that Canada's potential growth rate closely mimics the U.S. performance possibly reflecting the close real and financial ties between the two countries and the similar industrial/economic structure. ${ }^{22}$ Using European Commissions estimates for the United States and the EU-12 countries, we find that potential growth rates in 2008 in the EU-12 area, United States and Canada were substantially lower compared with the year 2000 (1 percentage point lower in the EU-12 countries, 1.4 percentage points lower in the

Canada, EU-12 and United States: Potential GDP Growth, 1981-2008 1/

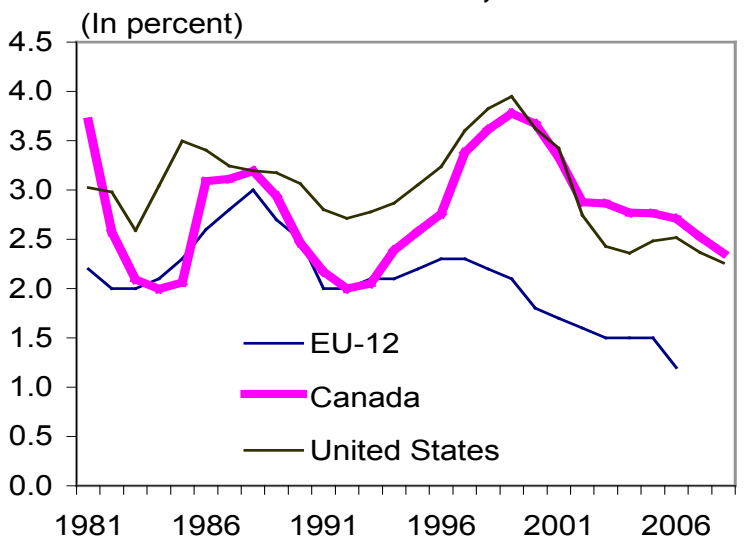

Sources: European Commission (2009); Barrera et al. (2009); and authors' calculations.

1/ Data for the United States are based on revised GDP data.

United States, and around

1.3 percentage points lower in Canada). Thus, the current crisis is only exacerbating the last decade's downward trend in all countries' potential growth rates. Interestingly, while in the past, U.S. potential growth was systematically above Canada's, we find that the situation reversed in the 2000s, and should continue over the medium-term, given the largest negative implications for the U.S. economy from the crisis.

Our projections on potential GDP growth are broadly in line with other researchers. Despite some minor differences in our NAIRU forecasts compared to the OECD, the shape of potential growth estimates are essentially the same for 2009 and 2010. Similarly, the Bank of Canada's (2009) numbers are only 30 basis points lower than ours for 2009, and the same for 2010 (the main difference lies in estimates for potential output in 2008). Over the medium term, we have the same potential growth outlook as the Bank of Canada (at around 2 percent), though we have a more gradual recovery in growth rates than expected by the

\footnotetext{
${ }^{22}$ For a discussion on the methodology used to construct the U.S. potential growth series, please refer to Barrera et al. (2009). Our estimates of U.S. potential growth differ slightly from theirs, as we incorporate recent revisions in GDP data which occurred following the publication of their study.
} 
Bank. Given however, our high potential GDP growth for 2008, we have a much higher output gap for 2009 (at around 5 percent of potential) versus a 4 percent by the Bank of Canada. Similarly, our projections are broadly in line with the ones recently released by Bishop and Burleton (2009).

\begin{tabular}{|lccccc|}
\hline \multicolumn{5}{c|}{ Comparing Potential GDP Projections } \\
\hline & 2008 & 2009 & 2010 & 2011 & 2014 \\
\cline { 2 - 7 } & 2.4 & 1.5 & 1.5 & 1.7 & 2.0 \\
Authors & 1.7 & 1.2 & 1.5 & 1.9 & $\cdots$ \\
Bank of Canada & 2.5 & 1.2 & 1.3 & 1.8 & $\cdots$ \\
Bishop and Burleton & 2.3 & 1.8 & 1.5 & $\cdots$ & $\cdots$ \\
\hline SECD & \multicolumn{7}{c}{} \\
Sources: Bank of Canada (2009); OECD; Bishop and Burleton (2009); \\
and author's projections.
\end{tabular}

\section{A Look at Past Canadian Recessions}

The current recession closely mimics the 1980s in terms of its severity and composition (Table 2). In the 1980s and 1990s recessions, capital services were the main force behind reductions in potential GDP. In the 1982 recession, private investment fell by 13.7 percent; similar declines are expected for 2009 as well. As indicated in Table 2, a large decline in potential GDP growth resulted from this deceleration in capital stock accumulation in 1982, removing more than 1 percentage point from Canada's estimated potential growth. In contrast, labor services and TFP contributions were essentially unchanged during recessions of the 1980s and 1990s.

\begin{tabular}{|c|c|c|c|c|c|c|}
\hline \multicolumn{7}{|c|}{ Growth Rate during previous recessions } \\
\hline \multirow[b]{2}{*}{$G D P$} & \multirow{2}{*}{$\begin{array}{r}1982 \\
-2.9\end{array}$} & \multirow{2}{*}{$\begin{array}{r}1983 \\
2.7\end{array}$} & \multirow{2}{*}{$\begin{array}{l}1991 \\
-2.1\end{array}$} & \multirow{2}{*}{$\begin{array}{c}1992 \\
0.9\end{array}$} & \multicolumn{2}{|c|}{$\begin{array}{c}20092010 \\
\text { Proj. }\end{array}$} \\
\hline & & & & & -2.5 & 2.1 \\
\hline Consumption & -2.5 & 2.6 & -1.6 & 1.5 & -0.1 & 2.2 \\
\hline Private Investment & -13.7 & -0.5 & -7.1 & -3.0 & -13.5 & 0.0 \\
\hline Government Spending & 2.5 & 1.1 & 3.1 & 0.7 & 3.9 & 4.1 \\
\hline Exports & -1.6 & 5.9 & 1.8 & 7.2 & -13.8 & 3.7 \\
\hline Imports & -16.1 & 10.0 & 2.5 & 4.7 & -14.8 & 4.7 \\
\hline
\end{tabular}

In this recession, the adjustment in potential growth would be explained roughly equally by lower contributions of both labor and capital services. During this recession, the projected 
increase in the NAIRU (which, at about 0.4 percentage points by the end of 2010 , lies between the larger increase in the early 1980s and unchanged levels in the early 1990s) has a significant impact on potential GDP growth. This contribution is subject to large uncertainty, though, given the ongoing restructuring in the Canadian economy.

Moving forward, we expect the recovery in potential GDP to closely mimic past crises. Similar to the 1982 and 1991 recession, potential growth rate over the medium term does not return to its pre-crisis levels, reflecting the declining trend since the 2000s, and demographic developments.

\section{Conclusions ANd Policy IMPLiCATIONS}

This paper estimates the impact of the financial crisis on potential growth in Canada. According to our estimates, the economic crisis would lead to a sharp downward revision in potential growth rates for Canada in the next two years. Bearing in mind the considerable technical and economic uncertainties (also highlighted among others, in Koopman and Székely, 2009) we find that the immediate impact of the crisis on potential GDP growth could be severe-falling by almost 1 percentage point. The effects over the medium term are less clear: we expect Canadian potential growth to gradually rise to around 2 percent — only a bit lower than its 2008 rate, with the decline mostly reflecting the effects of population aging and the continuing decline in working hours.

What do our estimates imply for policymakers? To start with, data suggest that Canada's output gap is still considerably large, implying that the current accommodating stance for monetary and fiscal policies should stay in place. Moving forward, the crisis would have a permanent impact on Canada's potential GDP level, implying that policies to raise potential growth would be worth considering. These could include enabling private R\&D investment (which is low in Canada in international comparisons), facilitating internal trade, reducing foreign ownership barriers where possible (including telecommunications, airlines and broadcasting), removing obstacles that hinder elderly labor force participation, and ensuring that incentives do not hinder firms from growing larger. ${ }^{23} 24$

That said, Canada's outlook on potential growth appears favorable in international comparisons. The strong macroeconomic and financial stability frameworks in place have

\footnotetext{
${ }^{23}$ Pilat (2005) finds that Canada lags many OECD countries in innovative performance and may have some scope for further catch-up. However, it notes that Canadian investment in R\&D is unlikely to catch up with the R\&D intensity recorded in some OECD countries, as it is limited by the structural composition of the economy-i.e., without a large high-tech industry—and by a relatively small average firm size.

${ }^{24}$ For a more extensive discussion of possible structural reforms that could raise productivity in Canada, the reader is referred to OECD (2004 and 2006) and Bishop and Burleton (2009).
} 
enabled Canada to weather the crisis better than most, and would be pivotal in supporting its recovery in the next few years. The authorities are considering or are already implementing many of the recommendations noted above as highlighted in Advantage Canada (2006)—the authorities' economic plan to increase Canada's competitiveness, including lowering corporate income taxation (at the provincial and federal level) and eliminating capital taxes, while they are considering (and are expected to act promptly on) the recommendations of the Competition Policy Review Panel (2008) to enhance competition and productivity. 


\section{REFERENCES}

Akerlof, G.A., W.T. Dickens, and G.L. Perry (2000), "Near-Rational Wage and Price Setting and the Optimal Rates of Inflation and Unemployment," Brookings Papers on Economic Activity, Vol. 1, pp. 1-44, The Brookings Institute.

Armstrong, P., T.M. Harchaoui, C. Jackson, and F. Tarkhani (2002), “A Comparison of Canada-U.S. Economic Growth in the Information Age, 1981-2000: The Importance of Investment in Information and Communication Technologies," in Productivity Growth in Canada-2002, Statistics Canada, Catalogue No. 15-204, Chapter 1, December.

Balakrishnan, R. (2008), “Canadian Firm and Job Dynamics,” IMF Working Paper No. 08/31, International Monetary Fund.

Baldwin, J. and W. Gu (2009), "Productivity Performance in Canada, 1961 to 2008: An Update on Long-term Trends," The Canadian Productivity Review No. 025, August 2009, Statistics Canada.

Ball, L. (2009), "Hysteresis in Unemployment: Old and New Evidence," NBER Working Paper Series No. 14818, March, National Bureau of Economic Research.

Bank of Canada (2009), Monetary Policy Report, October.

Bank of Canada (2008), Monetary Policy Report, April.

Bank of Canada (2005), Monetary Policy Report, October.

Bank of Canada (2002), Monetary Policy Report, October.

Barrera, N., M. Estevão, and G. Keim (2009), "U.S. Potential Growth in the Aftermath of the Crisis," IMF Country Report No. 09/229, International Monetary Fund.

Bassanini, A. and R. Duval (2006), "Employment Patterns in OECD Countries: Reassessing the Role of Policies and Institutions," OECD Economics Department Working Papers No. 486, Organization of Economic Co-operation and Development.

Betcherman, G. (2000), "Structural Unemployment: How Important Are Labor Market Policies and Institutions?" Canadian Public Policy, Vol. XXVI Special Issue on Structural Unemployment, Supplement 1. 
Bishop, G. and D. Burleton (2009), “A New Normal: Canada's Potential Growth During Recovery and Beyond," TD Economics Special Report, November.

Blanchard, O. and L.H. Summers (1989), "Hysteresis in Unemployment," NBER Working Paper No. 2035, National Bureau of Economic Research.

Cardarelli, R. (2004), "The Canada-United States Productivity Gap: Evidence from Industry Data," IMF Country Report No. 04/60, International Monetary Fund.

Cardarelli, R. and A. Kose (2004), "Economic Integration, Business Cycle, and Productivity in North America," IMF Working Paper No. 04/138, International Monetary Fund.

Cerra, V. and S. Saxena (2008), "Growth Dynamics: The Myth of Economic Recovery," American Economic Review, Vol. 98(1), pp. 439-457.

Competition Policy Review Panel (2008), Compete to Win, June, Government of Canada.

Cotis, J.P., J. Elmeskov, and A. Mourougane (2005), "Estimates of Potential Output: Benefit and Pitfalls From a Policy Perspective," in L. Rechling (ed.) Euro Area Business Cycle: Stylized Facts and Measurement Issues, CERP London.

Debelle G. and J. Vickery (1998), "The Macroeconomics of Australian Unemployment”, in RBA Annual Conference Volume in: G. Debelle and J. Borland (ed.), Unemployment and the Australian Labor Market, Reserve Bank of Australia.

Department of Finance Canada (2006), Advantage Canada: Building a Strong Economy for Canadians.

Eckstein, O. and R. Brinner (1972), "The Inflation Process in the United States," Joint Economic Committee of the Congress of the United States, Washington, DC: Government Printing Office.

Elmeskov, J. and K. Pichelman (1993), "Unemployment and Labor Force Participation: Trend and Cycle", OECD Economics Department Working Papers No. 130, Organization of Economic Co-operation and Development.

Estevão, M. and T. Severo (2009), "Financial Shocks and TFP Growth," forthcoming IMF Working Paper.

European Commission (2009), "Impact of the Current Economic and Financial Crisis on Potential Output," Occasional Papers No. 49, June 2009, Directorate-General for Economic and Financial Affairs. 
Fortin, M. and P. Fortin (1999), "The Changing Labor Force Participation of Canadians, 1969-96: Evidence from a Panel of Six Demographic Groups," in A Symposium on Canadian Labour Force Participation in the 1990s, Special Issue of Canadian Business Economics, Vol. 7, No. 2, May.

Fortin, P. (2000), "Macroeconomic Unemployment and Structural Unemployment," Canadian Public Policy, Vol. 26 (1), pp. 125-30.

Furceri, D. and A. Mourougane (2009), "The Effect of Financial Crises on Potential Output: New Empirical Evidence From OECD Countries,” Economic Department Working Paper, No. 699, Organization of Economic Co-operation and Development.

Haugh, D., P. Ollivaud, and D. Turner (2009), "The Macroeconomic Consequences of Banking Crises in OECD Countries,” OECD Working Paper No 683, Organization of Economic Co-operation and Development.

International Monetary Fund (2009a), World Economic Outlook, Sustaining the Recovery, October.

International Monetary Fund (2009b), World Economic Outlook, Crisis and Recovery, April.

International Monetary Fund (2008), Canada: 2008 Article IV Consultation-Staff Report, Country Report No. 08/69, February.

Jackson, A. (2005), “The NAIRU and Macro-economic Policy in Canada," Research Paper No. 12, Canadian Labor Congress.

Koopman, G.J. and I.P. Székely (2009), "The Financial Crisis and Potential Growth: Policy Challenges for Europe," ECFIN Economic Brief, Issue 3, June.

Modigliani, F. and L. Papademos (1975), "Targets for Monetary Policy in the Coming Year," Brookings Papers on Economic Activity, Economic Studies Program, Vol. 6 (19751), pp. 141-66, The Brookings Institution.

OECD (2006), Canada: OECD Economic Surveys, June.

OECD (2004), Canada: OECD Economic Surveys, December.

OECD (1996), Canada: OECD Economic Surveys, November.

Okun, A.M. (1973), “Upward Mobility in a High-Pressure Economy,” Brookings Papers on Economic Activity, Vol. 1, pp. 207-52, The Brookings Institution. 
Pilat, D. (2005), “Canada's Productivity Performance in International Perspective," International Productivity Monitor, No. 10, Spring.

Rao, S., A. Sharpe, and J. Smith (2005), "An Analysis of the Labor Productivity Growth Slowdown in Canada Since 2000," International Productivity Monitor, No. 10, Spring, Centre for the Study of Living Standards.

Rao, S., J. Tang and W. Wang (2008), "What Explains the Canada-US Labor Productivity Gap?” Canadian Public Policy, Vol. XXXIV, No. 2.

Ravn, M.O and H. Uhlig (2002), "On Adjusting the Hodrick-Prescott Filter for the Frequency of Observations," The Review of Economics and Statistics, Vol. 84(2), pp. 371-375.

Reinhard, C.M. and K. Rogoff (2009), "The Aftermath of Financial Crises,” NBER Working Paper No. 14656, National Bureau of Economic Research.

Richardson, P., L. Boone, C, Giorno, M. Meacci, D. Rae, and D. Turner (2000), "The Concept, Policy Use and Measurement of Structural Unemployment: Estimating a Time Varying NAIRU Across 21 OECD Countries," OECD Economics Department Working Papers No.250, Organization of Economic Co-operation and Development.

Robidoux, B. and B.S. Wong (2003), "Has Trend Productivity Growth Increased in Canada?" International Productivity Monitor, No. 6, Centre for the Study of Living Standards. Rose, D. E. (1988), "The NAIRU in Canada: Concepts, Determinants and Estimates," Technical Report No. 50, Bank of Canada.

Setterfield, M. A., D.V. Gordon and L. Osberg (1992), "Searching For a Will o' the Wisp; An Empirical Study of the NAIRU in Canada," European Economic Review, Vol. 36(1), pp. 119-36.

Sharpe, A. (2001), "A Comparison of Canadian and U.S. Labor Market Performance, 19892000," CSLS Research Report No.011m, Centre for the Study of Living Standards.

----- (1996), “The Canada-U.S. Unemployment Rate Gap: An Assessment of Possible Causes." Human Resources Development Canada, Strategic Policy, Applied Research Branch Research Paper R-96-15E.a., Ottawa.

Sharpe, A. and J. Arsenault (2009), "New Estimates of Multifactor Productivity Growth for the Canadian Provinces," International Productivity Monitor No. 18, pp. 25-37, Spring, Centre for the Study of Living Standards. 
Sharpe, A., J. Arsenault, and P. Harrison (2008), "Why Have Real Wages Lagged Labor Productivity Growth in Canada," International Productivity Monitor, No. 17, pp. 1627, Fall, Centre for the Study of Living Standards.

Sharpe, A. and T.C. Sargent (2000), "Structural Aspects of Unemployment in Canada: Introduction and Overview," Canadian Public Policy, Vol. XXVI, Supplement.

Staiger, D., J. Stock and M. W. Watson (1997), “The NAIRU, Unemployment and Monetary Policy," Journal of Economic Perspectives, American Economic Association, Vol. 11(1), pp. 33-49.

Statistics Canada (2007a), "Long-Term Productivity Growth in Canada and the United States," The Canadian Productivity Review, Research Paper No. 013.

------ (2007b), “Depreciation Rates for the Productivity Accounts," The Canadian Productivity Review, Research Paper No. 005.

Stiglitz, J. (1997), "Reflections on the Natural Rate Hypothesis," Journal of Economic Perspective, Vol. 11, No. 1, pp. 3-10.

Tobin, J. (1972), "Inflation and Unemployment," American Economic Review, Vol. 62, pp. $1-18$.

Tsounta, E. (2006), "Why are Women Working So Much More in Canada? An International Perspective," IMF Working Paper No. 06/92, International Monetary Fund. 
Figure 1. Canada: Potential Output Growth
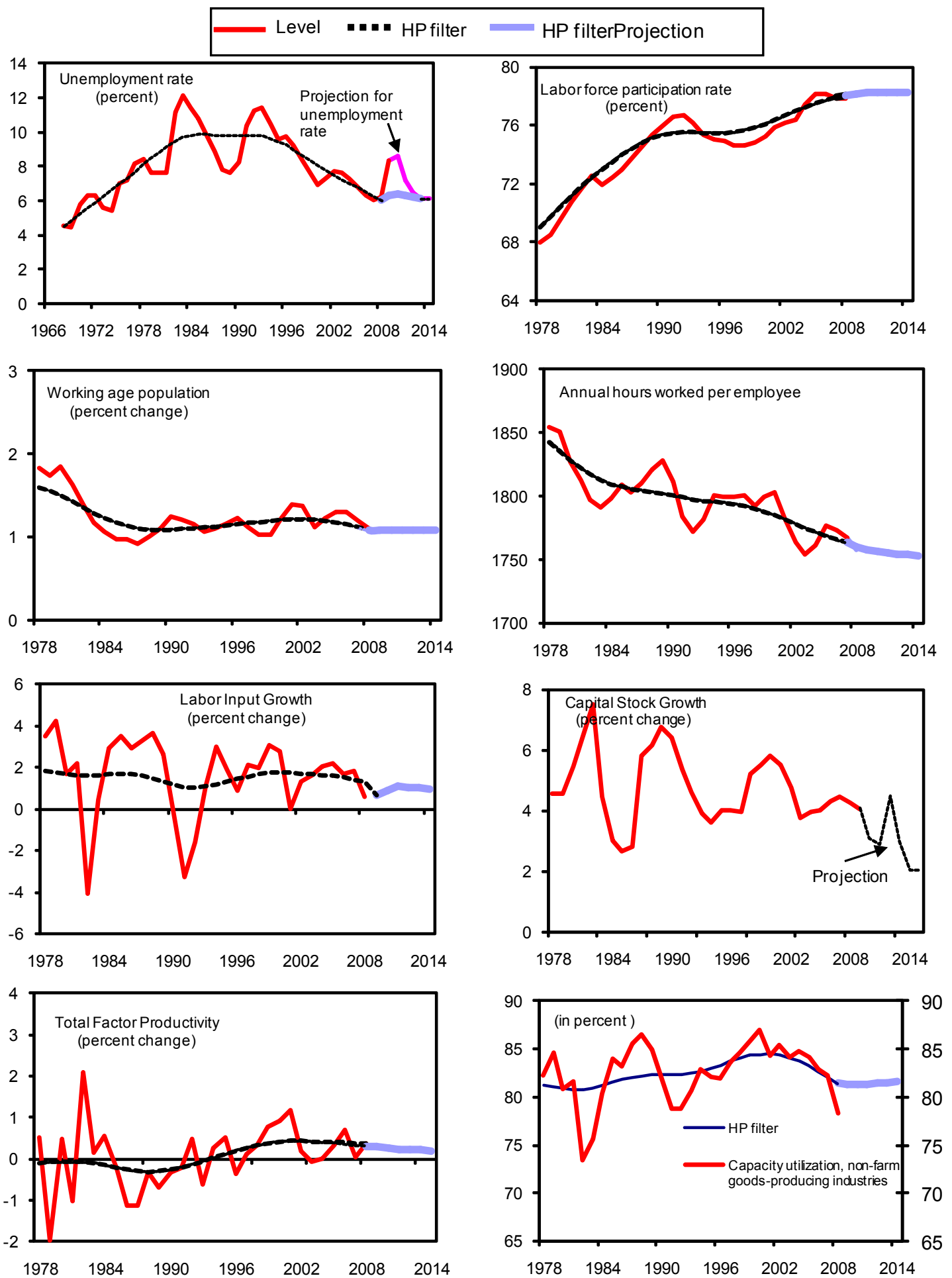

Source: Haver Analytics; WEO; OECD; and authors' calculations. 
Table 1. Path for Potential Output Growth Components 1/

\begin{tabular}{|c|c|c|c|c|c|c|c|c|c|c|c|}
\hline & \multirow[b]{2}{*}{$1977-94$} & \multirow[b]{2}{*}{ 1995-99 } & \multirow[b]{2}{*}{ 2000-04 } & \multirow[b]{2}{*}{ 2005-08 } & \multirow[b]{2}{*}{2008} & \multicolumn{6}{|c|}{ Projections } \\
\hline & & & & & & 2009 & 2010 & 2011 & 2012 & 2013 & 2014 \\
\hline Potential Growth, percentage change & 2.6 & 3.2 & 3.1 & 2.6 & 2.4 & 1.5 & 1.5 & 1.7 & 1.8 & 1.9 & 2.0 \\
\hline Capital Services, percentage change & 5.0 & 5.3 & 4.3 & 3.5 & 4.1 & 2.2 & 1.8 & 2.1 & 2.4 & 2.8 & 3.2 \\
\hline Stock of Capital, percentage change & 4.9 & 4.9 & 4.4 & 4.3 & 4.1 & 2.3 & 1.9 & 2.0 & 2.3 & 2.6 & 3.1 \\
\hline Capacity Utilization, percentage change & 0.1 & 0.4 & -0.1 & -0.7 & -0.8 & -0.1 & -0.1 & 0.1 & 0.1 & 0.1 & 0.1 \\
\hline Capacity Utilization, percentage points : & 81.7 & 83.7 & 84.3 & 82.4 & 81.5 & 81.4 & 81.3 & 81.4 & 81.5 & 81.6 & 81.7 \\
\hline Labor Services, percentage change & 1.5 & 1.5 & 1.7 & 1.4 & 1.3 & 0.7 & 0.9 & 1.1 & 1.0 & 1.0 & 0.9 \\
\hline NAIRU & -0.1 & 0.3 & 0.3 & 0.3 & 0.3 & -0.3 & -0.1 & 0.1 & 0.1 & 0.1 & 0.0 \\
\hline NAIRU, percentage points $3 /$ & 9.4 & 8.9 & 7.5 & 6.4 & 6.0 & 6.3 & 6.4 & 6.3 & 6.2 & 6.1 & 6.1 \\
\hline Labor force participation rate & 0.6 & 0.2 & 0.4 & 0.2 & 0.1 & 0.1 & 0.1 & 0.0 & 0.0 & 0.0 & 0.0 \\
\hline $\begin{array}{l}\text { Labor force participation rate, } \\
\text { percentage points } 4 /\end{array}$ & 73.5 & 75.7 & 76.9 & 77.9 & 78.1 & 78.2 & 78.2 & 78.3 & 78.3 & 78.3 & 78.3 \\
\hline $\begin{array}{l}\text { Annual hours worked per employee, } \\
\text { percentage change } 5 /\end{array}$ & -0.2 & -0.1 & -0.2 & -0.2 & -0.2 & -0.2 & -0.1 & 0.0 & -0.1 & 0.0 & 0.0 \\
\hline $\begin{array}{l}\text { Working age population, } \\
\text { percentage change } 6 /\end{array}$ & 1.3 & 1.2 & 1.2 & 1.1 & 1.1 & 1.0 & 1.0 & 1.0 & 1.0 & 0.9 & 0.9 \\
\hline $\begin{array}{l}\text { Total Factor Productivity, } \\
\text { percentage change }\end{array}$ & -0.2 & 0.3 & 0.4 & 0.3 & 0.3 & 0.3 & 0.3 & 0.2 & 0.2 & 0.2 & 0.2 \\
\hline
\end{tabular}

Contributions to Potential Output Growth 1/

(Percentage points)

\begin{tabular}{|c|c|c|c|c|c|c|c|c|c|c|c|}
\hline & \multirow[b]{2}{*}{ 1977-94 } & \multirow[b]{2}{*}{ 1995-99 } & \multirow[b]{2}{*}{ 2000-04 } & \multirow[b]{2}{*}{ 2005-08 } & \multirow[b]{2}{*}{2008} & \multicolumn{6}{|c|}{ Projections } \\
\hline & & & & & & 2009 & 2010 & 2011 & 2012 & 2013 & 2014 \\
\hline Potential Growth & 2.6 & 3.2 & 3.1 & 2.6 & 2.4 & 1.5 & 1.5 & 1.7 & 1.8 & 1.9 & 2.0 \\
\hline Capital Services 1/ & 1.9 & 2.0 & 1.6 & 1.3 & 1.5 & 0.8 & 0.7 & 0.8 & 0.9 & 1.1 & 1.2 \\
\hline Stock of Capital & 1.9 & 1.9 & 1.7 & 1.6 & 1.5 & 0.9 & 0.7 & 0.7 & 0.9 & 1.0 & 1.2 \\
\hline Capacity Utilization & 0.0 & 0.1 & 0.0 & -0.3 & -0.3 & 0.0 & 0.0 & 0.0 & 0.0 & 0.0 & 0.0 \\
\hline Labor Services & 0.9 & 1.0 & 1.1 & 0.9 & 0.8 & 0.4 & 0.5 & 0.7 & 0.6 & 0.6 & 0.6 \\
\hline NAIRU 3/ & -0.1 & 0.2 & 0.2 & 0.2 & 0.2 & -0.2 & -0.1 & 0.1 & 0.1 & 0.1 & 0.0 \\
\hline Labor force participation rate 4/ & 0.3 & 0.1 & 0.2 & 0.1 & 0.1 & 0.1 & 0.0 & 0.0 & 0.0 & 0.0 & 0.0 \\
\hline Annual hours worked per employee $\varepsilon$ & -0.1 & -0.1 & -0.1 & -0.1 & -0.1 & -0.1 & -0.1 & 0.0 & 0.0 & 0.0 & 0.0 \\
\hline Working age population $6 /$ & 0.8 & 0.7 & 0.8 & 0.7 & 0.8 & 0.6 & 0.6 & 0.6 & 0.6 & 0.6 & 0.6 \\
\hline Total Factor Productivity & -0.2 & 0.3 & 0.4 & 0.3 & 0.3 & 0.3 & 0.3 & 0.2 & 0.2 & 0.2 & 0.2 \\
\hline
\end{tabular}

Sources: Haver Analytics; WEO; OECD; and staff estimates.

1/ Output-labor elasticity assumed to be 0.6 and output-capital elasticity assumed to be 0.4 , see Sharpe, Arsenault and Harrison (2008).

2/ Trend capacity utilization is calculated using data from Stats Canada (detrended by HP-filter).

3/ Non-accelerating inflation rate of unemployment. HP filter of civilian unemployment rate, 15-64 years (seasonally adjusted).

4/ Trend labor force participation rate calculated by applying the HP filter of the ratio between labor force and working age population.

5/ Trend changes in annual hours work per employee is calculated by applying the HP filter of annual hours worked per employee

in the total economy

6/ Working-age population refers to Canadian population 16-65 years of age. Projections as published by Stats Canada. 
Table 2. Path for Potential Output Growth Components During Recent Canadian Downturns 1/

\begin{tabular}{|c|c|c|c|c|c|c|c|c|c|c|c|c|}
\hline & \multirow[b]{2}{*}{1981} & $\downarrow$ & \multicolumn{3}{|c|}{ Recessions } & $\downarrow$ & \multirow[b]{2}{*}{1992} & \multirow[b]{2}{*}{ 1993-1996 } & \multirow[b]{2}{*}{2008} & \multicolumn{3}{|c|}{ Projections } \\
\hline & & 1982 & 1983 & $1984-87$ & 1990 & 1991 & & & & 2009 & 2010 & 2011-14 \\
\hline Potential Growth, percentage change & 3.7 & 2.6 & 2.1 & 2.6 & 2.5 & 2.2 & 2.0 & 2.4 & 2.4 & 1.5 & 1.5 & 1.8 \\
\hline Capital Services, percentage change & 7.4 & 4.4 & 3.2 & 4.7 & 5.4 & 4.6 & 4.0 & 4.2 & 3.2 & 2.2 & 1.8 & 2.6 \\
\hline Stock of Capital, percentage change & 7.5 & 4.4 & 3.0 & 4.4 & 5.4 & 4.6 & 3.9 & 3.9 & 4.1 & 2.3 & 1.9 & 2.5 \\
\hline Capacity Utilization, percentage change & -0.1 & 0.0 & 0.2 & 0.4 & 0.0 & 0.0 & 0.1 & 0.3 & -0.8 & -0.1 & -0.1 & 0.1 \\
\hline Capacity Utilization, percentage points 2 . & 80.8 & 80.8 & 80.9 & 81.7 & 82.3 & 82.3 & 82.3 & 82.9 & 81.5 & 81.4 & 81.3 & 81.5 \\
\hline Labor Services, percentage change & 1.6 & 1.6 & 1.6 & 1.6 & 1.1 & 1.0 & 1.0 & 1.3 & 1.3 & 0.7 & 0.9 & 1.0 \\
\hline NAIRU & -0.4 & -0.3 & -0.3 & 0.0 & 0.0 & 0.0 & 0.0 & 0.2 & 0.3 & -0.3 & -0.1 & 0.1 \\
\hline NAIRU, percentage points $3 /$ & 9.1 & 9.4 & 9.7 & 9.8 & 9.8 & 9.8 & 9.8 & 9.5 & 6.0 & 6.3 & 6.4 & 6.2 \\
\hline Labor force participation rate & 0.9 & 0.8 & 0.8 & 0.6 & 0.2 & 0.1 & 0.0 & 0.0 & 0.1 & 0.1 & 0.1 & 0.0 \\
\hline $\begin{array}{l}\text { Labor force participation rate, } \\
\text { percentage points } 4 /\end{array}$ & 71.8 & 72.4 & 73.0 & 74.2 & 75.5 & 75.5 & 75.5 & 75.5 & 78.1 & 78.2 & 78.2 & 78.3 \\
\hline $\begin{array}{l}\text { Annual hours worked per employee, } \\
\text { percentage change } 5 /\end{array}$ & -0.3 & -0.3 & -0.2 & -0.1 & -0.1 & -0.1 & -0.1 & -0.1 & -0.2 & -0.2 & -0.1 & 0.0 \\
\hline $\begin{array}{l}\text { Working age population, } \\
\text { percentage change } 6 /\end{array}$ & 1.4 & 1.4 & 1.3 & 1.2 & 1.1 & 1.1 & 1.1 & 1.1 & 1.1 & 1.0 & 1.0 & 1.0 \\
\hline $\begin{array}{l}\text { Total Factor Productivity, } \\
\text { percentage change }\end{array}$ & -0.1 & -0.1 & -0.1 & -0.2 & -0.3 & -0.2 & -0.1 & 0.1 & 0.3 & 0.3 & 0.3 & 0.2 \\
\hline
\end{tabular}

\section{Contributions to Potential Output Growth 1/}

(Percentage points)

\begin{tabular}{|c|c|c|c|c|c|c|c|c|c|c|c|c|}
\hline & \multirow[b]{2}{*}{1981} & \multirow{2}{*}{$\begin{array}{c}\downarrow \\
1982\end{array}$} & \multicolumn{3}{|c|}{ Recessions } & \multirow{2}{*}{$\frac{\downarrow}{\downarrow}$} & \multirow[b]{2}{*}{1992} & \multirow[b]{2}{*}{ 1993-1996 } & \multirow[b]{2}{*}{2008} & \multicolumn{3}{|c|}{ Projections } \\
\hline & & & 1983 & 1984-87 & 1990 & & & & & 2009 & 2010 & 2011-14 \\
\hline Potential Growth & 3.7 & 2.6 & 2.1 & 2.6 & 2.5 & 2.2 & 2.0 & 2.4 & 2.4 & 1.5 & 1.5 & 1.8 \\
\hline Capital Services 1/ & 2.8 & 1.7 & 1.2 & 1.8 & 2.0 & 1.7 & 1.5 & 1.6 & 1.2 & 0.8 & 0.7 & 1.0 \\
\hline Stock of Capital & 2.9 & 1.7 & 1.1 & 1.7 & 2.0 & 1.8 & 1.5 & 1.5 & 1.5 & 0.9 & 0.7 & 1.0 \\
\hline Capacity Utilization & -0.1 & 0.0 & 0.1 & 0.1 & 0.0 & 0.0 & 0.0 & 0.1 & -0.3 & 0.0 & 0.0 & 0.0 \\
\hline Labor Services & 1.0 & 1.0 & 1.0 & 1.0 & 0.7 & 0.6 & 0.6 & 0.8 & 0.8 & 0.4 & 0.5 & 0.6 \\
\hline NAIRU 3/ & -0.2 & -0.2 & -0.2 & 0.0 & 0.0 & 0.0 & 0.0 & 0.1 & 0.2 & -0.2 & -0.1 & 0.0 \\
\hline Labor force participation rate $4 /$ & 0.6 & 0.5 & 0.5 & 0.4 & 0.1 & 0.0 & 0.0 & 0.0 & 0.1 & 0.1 & 0.0 & 0.0 \\
\hline Annual hours worked per employee 5 & -0.2 & -0.2 & -0.1 & -0.1 & -0.1 & -0.1 & 0.0 & 0.0 & -0.1 & -0.1 & -0.1 & 0.0 \\
\hline Working age population $6 /$ & 0.9 & 0.8 & 0.8 & 0.7 & 0.7 & 0.7 & 0.7 & 0.7 & 0.7 & 0.6 & 0.6 & 0.6 \\
\hline Total Factor Productivity & -0.1 & -0.1 & -0.1 & -0.2 & -0.3 & -0.2 & -0.1 & 0.1 & 0.3 & 0.3 & 0.3 & 0.2 \\
\hline
\end{tabular}

Sources: Haver Analytics; WEO; OECD; and staff estimates.

1/ Output-labor elasticity assumed to be 0.6 and output-capital elasticity assumed to be 0.4 , see Sharpe, Arsenault and Harrison (2008).

2/ Trend capacity utilization is calculated using data from Stats Canada (detrended by HP-filter).

3/ Non-accelerating inflation rate of unemployment. HP filter of civilian unemployment rate, 15-64 years (seasonally adjusted).

4/ Trend labor force participation rate calculated by applying the HP filter of the ratio between labor force and working age population.

$5 /$ Trend changes in annual hours work per employee is calculated by applying the HP filter of annual hours worked per employee in the tota

6/ Working-age population refers to Canadian population 16-65 years of age. Projections as published by Stats Canada. 
ANNEX 1. DATA SourCeS

This annex describes data used in the growth accounting decomposition as described by equations (1) and (2), where output $\left(Y_{t}\right)$ is defined as the total-economy real Fisher chained GDP from Statistics Canada. All trend series have been obtained by smoothing the raw series using the Hodrick-Prescott filter.

\section{Capital Services}

Capital services are obtained by multiplying trend capital stock by trend capacity utilization. Trend capital stock is a smoothed version of the capital stock for the total economy (volume) available from OECD Economic Outlook No 85 (annual data). The trend capital growth is the growth in the capital stock before the adjustment for capacity utilization rate. Data on capacity utilization in the industrial sector (NAICS: Total industry) are available from Statistics Canada starting in 1988. In order to obtain a longer capacity utilization series, the pre-1988 data is estimated using the growth rates of capacity utilization for SIC: Nonfarm Goods-Producing Industries (SA).

\section{Labor Services}

Labor Services is obtained by multiplying (1-NAIRU) by trend labor force participation rate, trend average annual hours worked per employee and trend working-age population. All data are available from Statistics Canada's Labor Force Survey, where NAIRU is the trend unemployment rate (both sexes, 15 to 64 Years); labor force participation rate is the ratio of labor force (both sexes, 15 to 64 Years) divided by working- age population (both sexes, aged 15 to 64 Years); and average annual hours worked per employee are constructed by multiplying actual hours worked per week (all sectors) by 52 and dividing it by total employment (both sexes, 15 years and over).

\section{Trend TFP}

Trend TFP level is estimated by applying an HP filter to raw TFP level as estimated in equation (1). 